\title{
STUDENTS' PERCEPTION ON THE USE OF MEDIA OF ADVERTISEMENTS IN TEACHING SOCIOLINGUISTICS
}

\author{
Vina Fathira \\ Sekolah Tinggi Ilmu Bahasa Asing (STIBA) Persada Bunda \\ E-mail: vinafathira@gmail.com
}

\begin{abstract}
The researcher wanted to evaluate the students' opinion of using media of advertisements in order to get the deep description of the understanding of linguistic theory. Using media of advertisement is one of the techniques in increasing students' understanding of linguistic matters, especially in teaching sociolinguistics, especially in politeness and gender concept. In digital era, using media of advertisement is familiar media seen by the students that is using gadget actively. The research aims at students' perception of the use of media of advertisements in teaching sociolinguistics. The descriptive research was employed to this research. A group of students in a classroom using this media of advertisements is the population and the sample of this research. There were 10 students of the third year of STIBA Persada Bunda Pekanbaru through media of advertisement during 2017/2018 academic year. In collecting data, the students were asked to watch two videos from media of advertisements relating to politeness and gender. Then, in analysing data, the researcher used six questions relating to politeness and gender to the students by semi structured interview. The result indicated that most of the students motivated in obtaining information and enjoyed during the learning process and media of advertisement also increased their curiosity in understanding politeness and gender concepts of teaching sociolinguistics.
\end{abstract}

Keywords: Students' perception, media of advertisement, teaching sociolinguistics

\section{PERSEPSI MAHASISWA DALAM MENGGUNAKAN MEDIA IKLAN UNTUK PENGAJARAN SOCIOLINGUISTICS}

\begin{abstract}
Abstrak
Peneliti ingin mengetahui opini mahasiswa dengan menggunakan media iklan untuk memperoleh gambaran yang mendalam terkait dengan pemahaman teori linguistik. Penggunaan media iklan ini merupakan salah satu teknik dalam meningkatkan pemahaman mahasiswa dalam masalah linguistik, terutama dalam pengajaran sosiolinguistik, khususnya dalam konsep kesopanan dan gender. Dalam era digital, penggunaan media iklan merupakan media yang lazim dilihat oleh para mahasiswa tersebut yang menggunakan gadget secara aktif. Penelitian ini bertujuan untuk mengetahui persepsi mahasiswa dalam penggunaan media iklan dalam pengajaran sosiolionguistik. Penelitian ini merupakan penelitian deskriptif. Sejumlah mahasiswa dalam suatu kelas yang menggunakan media iklan merupakan populasi dan sekaligus sampel dalam penelitian ini. Terdapat 10 (sepuluh) orang mahasiswa dari tahun ketiga pada Sekolah Tinggi Ilmu Bahasa Asing (STIBA) Persada Bunda selama tahun ajaran 2017/2018. Dalam pengumpulan data, Peneliti meminta para mahasiswa untuk menonton 2 (dua) video dari media iklan yang sudah dipilih sebelumnya yang berkaitan dengan konsep kesopanan dan gender. Kemudian, dalam menganalisis data, peneliti menggunakan enam pertanyaan yang ditujukan kepada para mahasiswa tersebut
\end{abstract}


dengan menggunakan interview semi struktur. Hasil penelitian ini menunjukkan bahwa sebagian besar mahasiswa termotivasi dalam memperoleh informasi dan menikmati selama proses pembelajaran dan media iklan ini juga meningkatkan keingintahuan yang tinggi dalam memahami konsep kesopanan dan gender pada pengajaran sosiolinguistik.

Kata Kunci: Persepsi mahasiswa, media iklan, pengajaran sosiolinguistik

\section{BACKGROUND}

It is familiar to the students by using media like advertisement since they use gadget intensively. As development of the technology, the use of the social media becomes their daily activity so they become addicted day by day to the gadget (Siddiqui and Singh, 2016). In this research, the researcher took the advertisement from internet, since that advertisements related to electronic items were more factual and latest than nonelectronic items (Bansal and Gupta 2014: 672). In advertising language, it is the most language that can persuade and provoke the society's perception to certain purposes of an advertisement (Stamatelou, 2015: 29). The more valuable of the advertisement that there are animation, videos, and moving pictures (Harfoushi et al., 2016: 566).

In teaching sociolingustics as a branch of linguistics, it studies a relationship language and society (Holmes and Wilson, 2017: 1). While literally meaning, sociolinguistics is the study of the way language is affected by differences factors such as social classes, regions, sex and so on (Hornby, 2018). Actually, sociolinguistic is an easy subject to understand since it related to the society. However, it is hard for the students to understand the explanation of the sociolinguistic matters. Based on the research done by the researcher, the use of media of advertisement in understanding of the politeness and gender was the effective way to improve the students' understanding. In conclusion, the students' perception of the use of media of advertisement in understanding of the politeness and gender was interesting topic to be discussed in this research.

\subsection{The Aim of the Research}

In this research, the aim of the research was to find ot the students' perception of using media of advertisement in understanding of the politeness and gender concept.

\subsection{The Needs of the Research}

The needs to conduct the research was to evaluate the students' perception of the use of media of advertisement in understanding politeness and gender concept at university level are:

a. As the information for the lecturer about the students' perception of the use of media of advertisement in understanding gender and politeness concept.

b. As the information about the negative respon of students' perception of the use of media of advertisement in understanding politeness and gender concept.

c. As the information for the following researchers in conducting the research about the students' perception of the use of media of advertisement in understanding politeness and gender concept.

\subsection{Related Theories \\ 1.3.1 Politeness}

There are some experts that discusses the politeness concept. Polite includes talking to others in appropiate way from the speaker to the hearer (Holmes and Wilson, 2017: 268). In addition to, the politeness concept is also written in "The Palgrave Handbook of 
Linguistic (im)Politeness". Politeness is the basic point to asses somone's habit to others to be accepted and approved by others as part of habits of norms (Culpeper, Haugh and Kádár, 2017: 42).

In politeness concept, there is a definition of face concept based on the Brown \& Levinson theory. In sociolinguistic book, the definition of face that also related to positive and negative face. Face is defined as a positive self image of individual, while FTA or face-threatening act is a speech act that has potentially threated the speaker (Wardhaugh and Fuller, 2015: 405). Face consisted of two parts. First is positive face - the willingness to be approved and admired by others. Second is negative face - the unwillingness to be approved and admired by others (Wardhaugh and Fuller, 2014: 256-257; Pangestuti: 2015:8).

Politeness or polite can be defined as an action to minimize the effect that might happen face threatening act (FTA). Frequently, the terms of negative face and negative politeness were still in doubt. For that, the sociolinguists define the negative face as well as negative politeness. Negative face is a term of politeness theory that related to the someones's unwillingness to be approved and admired by others, whereas, the negative politeness is also a politeness theory related to linguistic startegy used by the speaker not to threat the negative face of the hearer (Wardhaugh and Fuller, 2015: 412).

Furthermore, the terms of positive face and positive politeness were defined by the sociolinguists that can be seen as follows. Positive face merupakan suatu konsep dari teori politeness that related to someone's willingness to be approved and admired by others, while positive politeness is part of linguistic strategy in politeness theory that is used for prevent the other positive faces. (Wardhaugh and Fuller, 2015: 414; Hameed, 2010:40)
In Brown and Levinson's theory about the politeness strategies quoted from other previous researhers, there are some strategies used in politness (Pangestuti, 2015: 7; Karimkhanlooei1 and Vaezi 2017:111-112). There are 4 politeness strategies that can be seen as follows. First is bald on-record strategy. It is a direct way of saying things. The examples are "Come in", "Pass me the bucket". Second is positive politeness strategy. This strategy showed that the speaker recognize the hearer has willingness to be approved. This strategy is part of positive face. The example is "You must be hungry after such a long journey, would you like something to eat?". Third is negative politeness strategy. This strategy used as a way to interact with the hearer in a non-imposing way. The example is "You must forgive me, but I forgot to bring your laptop". Four is off-record indirect strategy. It is used to remove the speaker form any potential of preventing the FTA with implicature, or with implied meaning, or ambigu. The example is "Perhaps someone should have call you first" "Wow, it's getting cold in here".

\subsubsection{Gender}

The definition of gender concept can be differentiated from the gender concept itself compare to linguistic concept. The gender concept does not easily define as a social construction of identity that related to thought of biological category of "sex" but it frequently discuss about 'masculinity' and 'feminity' that in opposite with 'male' and 'female' (Meyerhoff, 2018: 201). However, concept of gender related to linguistic aspect is defined as linguistic features in conncetion with the way of a group or certain gender in speaking (Wardhaugh and Fuller, 2015: 406). In line with the previous statement, other experts define gender as an assumption or thought about the differences of men and women 
habits (Culpeper, Haugh and Kádár, 2017: 71).

It is different from "sex"in a brief explanation. The basic features of gender conmpare to "sex" can be seen as follows. The term "sex" is biological category then gender is social and cultural category. Then, according to Holmes and Wilson (2017: 150), concept of gender focus on description of habitual utterances of masculin and feminim. In certain scale not in absolute category.

In sociolinguistics, language in terms of concept of politeness is closely related to gender, like in the politeness uttered by women. Mostly, either man or woman will talk or have conversation by using same language. Moreover, there are some differences between man language and woman languge. The differences of it can be seen in the features of women's language by Lakoff's theory.

Based on Lakoff's theory, there are 10 (ten) features of woman language. Holmes (2013: 286) said that 10 (ten) features of it as follows.

a. Lexical hedges or fillers, the example: "you know", "sort of", "well”, "you see".

b. Tag questions, the example: "she is very nice, isn't she?"

c. Rising intonations on declaratives, the example: "it's really good".

d. 'Empty' adjectives, the example: "divine", "charming", "cute".

e. Precise colour teams, the example: "magenta", "aquamarine".

f. Intensifiers such as just and so, the example: "I like him so much".

g. 'Hypercorrect' grammar, the example: consistent use of standard verbs forms.

h. 'Superpolite' forms, the example: indirect requests, euphemisms.

i. Avoidance of strong swears words, the example: "fudge", "my goodness".

j. Emphatic stress, the example: "it was a brilliant performance".

From ten features of women language, the researchers analyzed the learners' understanding of politeness and gender existed in media of advertisements.

\subsubsection{Advertising}

Advertising language is the most language that can persuade, provoke perception of the society to certain purposes of media of advertisement (Stamatelou, 2015: 29). Advertising language Advertising language also build 'relations' that facilitate the provoking perception of the degree of belief, the basic point that support of acceptance of the product and image. In short, media of advertisement builds the interpersonal relation between the adverstising maker and consumer.

Advertising language also builds an environment that provoke the perception of society to the degree of trust, reputation, and other things that support of product acceptance and image of media of advertisement. In short, media of advertisement builds interpersonal relation between advertiser and consumer.

\subsection{Related Findings}

In this part, researchers quoted several findings on gender, politeness and some others about media of advertisement to support the theories used in this research. The related findings were as follows:

a. Stamatelou (2015) discussed about the use of media of advertisement in increasing understanding in EFL language learning in the classroom. He stated that the purpose of article is to show why and how language learning at level a discource using written advertisements that contributed to language learning. This article is similar to the research by using advertisement as media in teachinglearning process, however, in this research the researcher wanted to evaluate the students' perception of the use media of advertisement in politeness and gender concept. 
b. Wambui (2014) examined the linguistic realization of politeness strategies and how the advertising language as a persuasive tool in banking advertisements. He used the theory of politeness by Brown and Stephen c. Levinson to explain how they manipulate language with the aim of persuading the their target (audience) to have products from their banks. The results showed that the media of advertisements had a number of variations of politeness strategies in positive way. This article used a qualitative method but not applying the media of advertisement in teaching-learning process. It was different from this research that wanted to evaluate the students' perception of the use media of advertisement in politeness and gender concept.

c. Saidi and Khosravi (2015) wrote in their article about perception of students of (im) politeness that discussed the differences that might appear on a certain gender. In this study, it focused on how gender of men and women responding about something if they are in the same situation. The results showed that both of two gender was almost same perception. The differences between perception of using (im) politeness tent to be done by men. This article is only about the perception of men and women gender in applying (im) politeness theory without using advertisement, however, in this research, the researcher wanted to evaluate the students' perception of the use media of advertisement in politeness and gender concept.

d. Elmianvari and Kheirabadi (2015) studied about politeness theory by Brown and Levinson. In this article, they asked their students to send email the teacher to make a request in the form of appropriate and in polite way. The result showed that the most students express their request into the form of a polite, formal, and indirect to avoid negative face. This previous research was only about the written tasks of the students without knowing the students' perception of the use media of advertisement in politeness and gender concept.

e. Pangestuti (2015) examined a research entitled "Politeness Strategies Used by Deddy Corbuzier in Interviewing Entertainer and Non-entertainer in Hitam Putih Talk Show". The aim of this research was to explain the types of differences and the reason of politeness strategies, used by Deddy Corbuzier as the host in interviewing guest from entertainer and nonentertainer. The results showed that the host tent to use the positive politeness strategy in interviewing entertainer. Instead, the host tend to use the bald on record strategy in interviewing non-entertainer. This previous research was only about qualitative research of a talk show in television, however, in this research the researcher wanted to evaluate the students' perception of the use media of advertisement in politeness and gender concept.

f. Aini (2016) examined a research entitled "Women Language Used by the Main Characters of "Mockingjay" Movie. The aim of this research to examine women's language generally used by the main character in the "Mockingjay" movie. Researcher used the women's language by Lakoff. The result showed that not all features of women's language found in the main characters of that movie. This previous research was about qualitative research in a movie however this research was about the student's perception of the use of media of advertisement of students' understanding in politeness and gender concept.

g. Khalik and Supatmiwati (2016) conducted a research on the function 
of pragmatics of politeness in media of advertisement. They analyzed 91 of English and Indonesian advertisements. The results showed that the use of politeness strategy indicated that the English advertisements tent to use off record, bald on record and positive politeness strategy, while Indonesian advertisement tent to use negative politeness strategy. This previous research was not about sociolinguistic analysis however the research was about teaching in politeness and gender concept.

\section{METHOD}

This study was a descriptive research, which aimed to evaluate the students' perception of the use of media of advertisement. This research was held at STIBA Persada Bunda located at Diponegoro street 42 Pekanbaru, Riau. The respondents of this research were all number of students that were the third year students of English Letter Department in 2017/2018 academic about 10 students. The researchers only focused on the students' perception of the use of media of advertisement in understanding politeness and gender concept.

\subsection{The Research Instrument}

The research instruments of this research in order to collect the data were six questions of semi-structured of interview. It aimed to gain the students' perception of understanding politeness and gender concept by using media of advertisement. The questions would be like in the following explanation. First, the question was about effective or not effective the use of media of advertisement to gain information of politeness and gender concept. Second, the question was about the positive effect of the use of media of advertisement in understanding politeness and gender concept. Third, the question was about the negative effect of the use of media of advertisement in understanding politeness and gender concept. Fourth, the question was about the existance of the features of women's language can be understood or not especially for geneder concept by Lakoff's theory. Fifth, the question was about the existance of the politeness startegies can be understood or not especially for politeness concept by Brown and Levinson's theory. Sixth, the question was about the preferences of media of advertisement watched by the students wheteher mostly men or mostly women video.

\subsection{The Data Collection Technique}

In collecting the data of this research, the researcher collected data by using interview to gain the information relate to students' perception of the use of media of advertisement in understanding politeness and gender concept. The type of interview used was semi-structured interview. This type of interview was suitable to this aim of research since the interview not asking directly only to the questions given, but also the reason needed related of each question to support the question itself. The procedures would be like this following explanation. First, the researcher asked the student one by one to have interview that had arranged before based on the need of this aim of the research. Second, prepared about six questions for the interview. The questions would be like:

a. Do you think media of advertisement is an effective technique to gain the information of politeness and gender concept?

$b$. What are the positive effect of using media of advertisement in politeness and gender concept?

c. What are the negative effect by using media of advertisement in politeness and gender concept?

d. Do you think that all of the features of women's language can be understood by looking at media of advertisement 
especially for gender concept by Lakoff's theory?

$e$. Do you think that all of the politeness strategies can be understood by looking at media of advertisement especially for politeness concept by Brown and Levinson's theory?

f. Which media of advertisement would you prefer to watch? An advertisement mostly women or mostly men?

\subsection{The Data Analysis Technique}

In analyzing the data of this research, after the students responded all the questions given about the students' perception of the use of media of advertisement in understanding politeness and gender, the researcher counted the response by the students and changed it into percentage of each question.

After calculating the students' responses, the researcher tried to draw the result of this research into diagram and gave some explanation relating to the diagram to explain the students' perception of the use of media of advertisement in understanding politeness and gender concept.

\section{FINDINGS AND DISCUSSION}

In this part, the researcher wanted to share some discussions of the questions distributed to the students about the students' perception of the use of media of advertisement in politeness and gender concept. There were 10 students attending sociolinguistics subject in Foreign Language College (STIBA) Persada Bunda participated to give response the questions in this research.

\section{Results of the semi-structured interview}

1. Do you think media of advertisement is an effective technique to gain the information of politeness and gender concept?

The related graph of the question "Media of advertisement as an Effective Tool" were responded as:

1. Effective technique 90 percentage

2. Not Effective technique 10 percentage
From the graph below, there were 9 students out of 10 that gave positive response to this question. Only 1 student thought that media of advertisement was not an effective technique. The percentage showed that the most dominant poin about 90 percentage was in positive response, "effective".

However, only 10 percentage was in negative response, not effective. It could be stated that the students perception of this question that was It was effective to the students in using media of advertisement in understanding politeness and gender concept. However, only one student did not give the positive response, as not effective because of the reason stated below:

Statment: "I think that it was not an effective, because I don't like the advertisement since I never watch television".

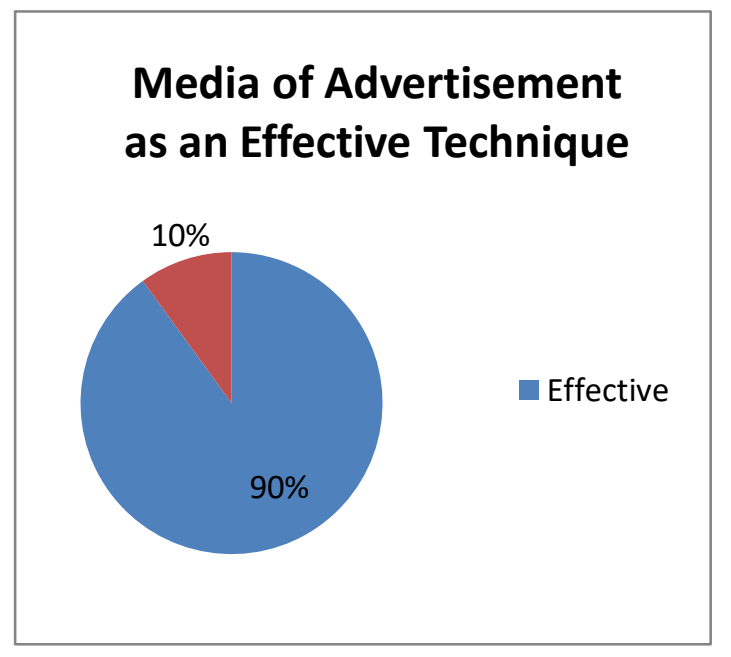

Diagram 1. Percentage of students'
perception about the use
of media of advertisement
as an effective technique

2. What are the positive effect of the use of media of advertisement in politeness and gender concept?

The responses of the students of the question "the positive effect of the use 
of media of advertisement in politeness and gender concept" were responded as:

1. Fun 10 percentage

2. Not boring 20 percentage

3. Motivating 40 percentage

4. Clear conversation 20 percentage

5. Understandable 10 percentage

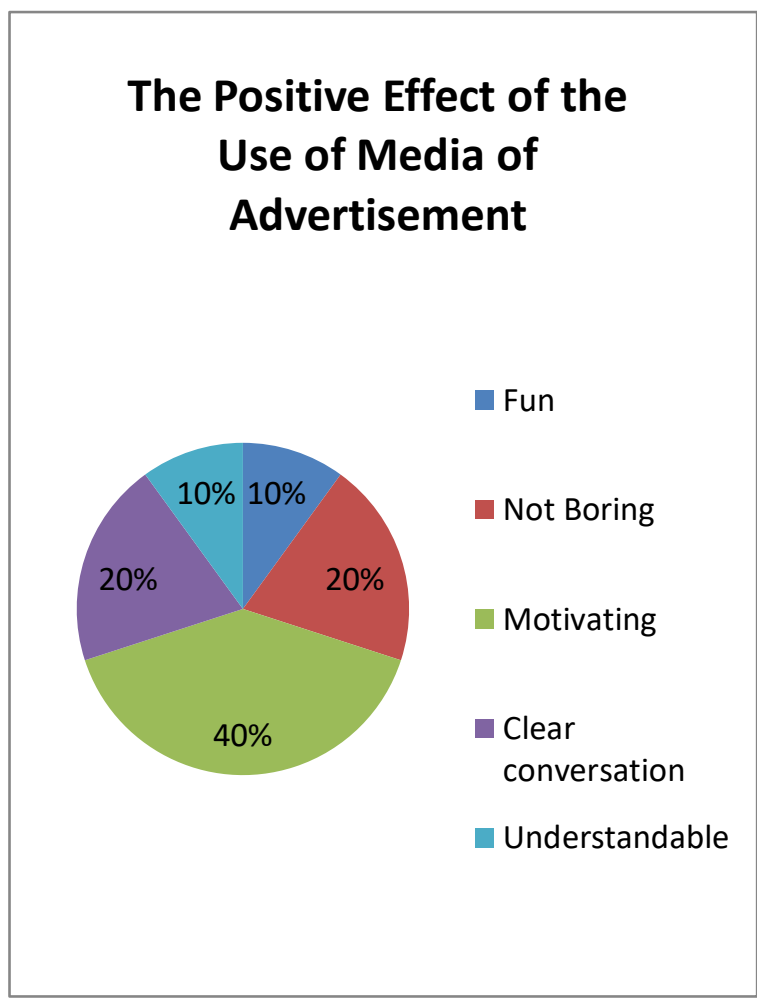

Diagram 2. Percentage of students' perception about the positive effect of the use of media of advertisement in politeness and gender concept

From the diagram above, it could be seen that there were 5 categories of responses. They are fun, not boring, motivating, clear conversation, and understandable. The percentage of the students' perception of the question "the positive effect of the use of media of advertisement ini politeness and gender concept" showed that the most dominant poin about 40 percentage responded "motivating". There were 2 (two) responses as "not boring" and "clear conversation" that were responded in the same range of percentage. The percentage of the response as "not boring" about 20 percentage. Then, the percentage of the response as "clear conversation" about 20 percent. Then, the two last responses of this question were responded as "fun" and "understandable", that were responded in the same range of percentage, about 10 percentage. It could be stated that the students perception of this question about the positive effect of the use of media of advertisement were "motivating", "not boring", "clear conversation", "fun", and "understandable' in order of the percentage range.

3. What are the negative effect of the use of media of advertisement in politeness and gender concept?

From this part of question, the result of the responses of the negative effect of the use of media of advertisement in politeness and gender can be seen in the following diagram.

The responses of the students of the question "the negative effect of the use of media of advertisement in politeness and gender concept" were responded as:

1. Only selected advertisements 20 percentage

2. Only few linguistic features 50 percentage

3. Not in normal setting 30 percentage

4. A lot of disturbing motions 10 percentage

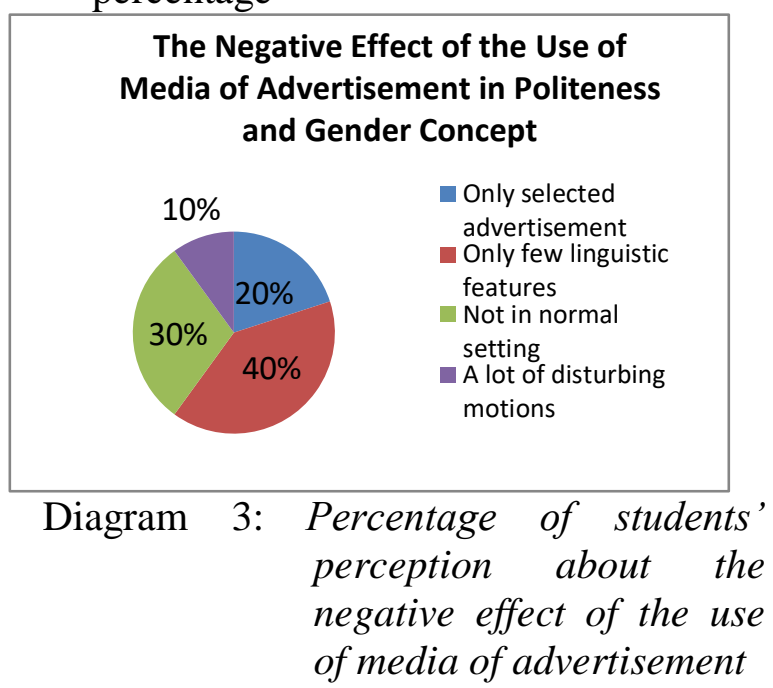


From the Diagram 3, it could be seen that there were 4 responses. They were "only selected advertisements", "only few linguistics features", "not in normal setting", and "a lot of disturbing motions".

The percentage of the students' perception of the question "the positive effect of the use of media of advertisement ini politeness and gender concept" showed that the most dominant poin about 50 percent responded "only selected advertisements". After that, some of the students gave the response as "not in normal setting" that was responded of 30 percent. Then, Not many students gave the response of this question as "only selected advertisement" of 20 percent. In a small number of student gave the response as "a lot of disturbing motions" of 10 percentage.

4. Do you think that all of the features of women's language can be understood by looking at media of advertisement especially for gender concept by Lakoff's theory?

The related graph of the question of "The students' perception of all of features of women's language can be understood by looking at media of advertisement especially for gender concept" were responded as:

1. Yes, sure 70 percentage

2. No, not existing all features 30 percentage

There were 7 students out of 10 that gave positive response, as "yes, sure" to this question. Only 3 students thought that media of advertisement was not giving all features of womens' language that gave negative response as "no, not existing all features".

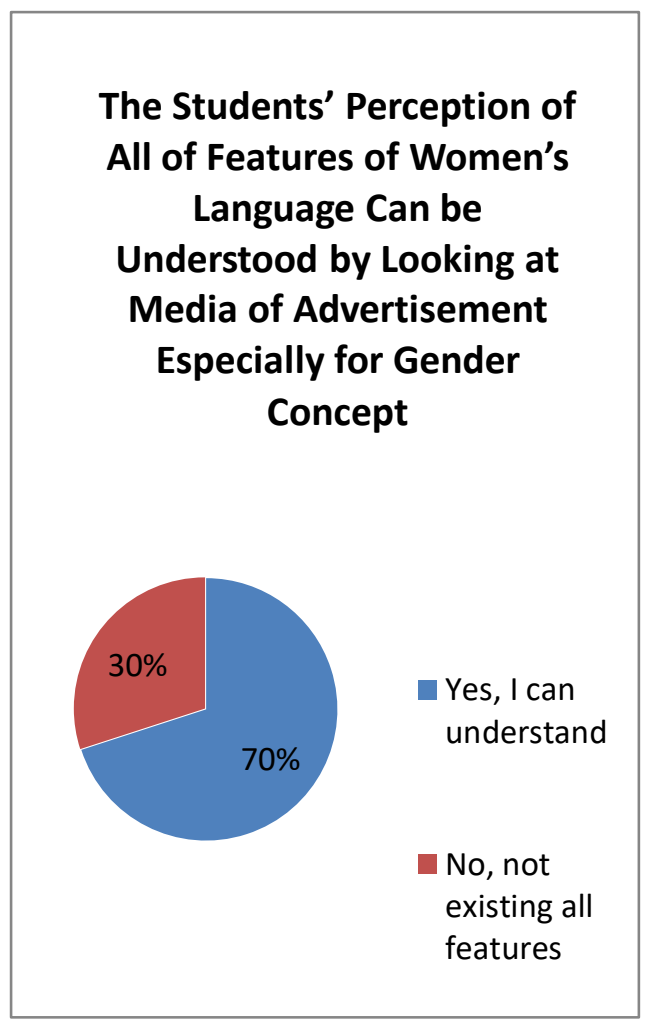

Diagram 4: Percentage of students' perception about finding and understanding the gender concept

From the diagram above, the percentage showed that the most dominant poin about 70 percentage was in positive response, "yes". However, only 30 percentage was in negative response, "no". It could be stated that the students perception of this question about the the use of media of advertisement was effective in understanding gender concept as women's language by Lakoff's theory.

It can be stated that based on Lakoff's theory, not all of 10 (ten) features of women's language existed of each media of advertisement. The 10 (ten) features of it as follows. First is lexical hedges or fillers. The example is "you know", "sort of", "well", "you see". Second is tag questions. The example is "she is very nice, isn't she?". The third is rising intonations on declaratives. The example is "it's really good". The fourth is 'Empty' adjectives. The example: "divine", "charming", "cute". The fifth is 
precise colour teams. The example: "magenta", "aquamarine". The sixth is intensifiers such as just and so, the example: "I like him so much". The seventh is 'Hypercorrect' grammar. The example is consistent use of standard verbs forms. The eight is 'Superpolite' forms. The example: indirect requests, euphemisms. The ninth is avoidance of strong swears words. The example: "fudge", "my goodness". The tenth is emphatic stress, the example: "it was a brilliant performance". From ten features of women's not all fetaures existed in the media of advertisement so it was being negative response to the students' perception.

5. Do you think that all of the politeness strategies can be understood by looking at media of advertisement especially for politeness concept by Brown and Levinson theory?

There were 8 students out of 10 that gave positive response, as "yes, sure" to this question. Only 2 students thought that media of advertisement was not giving all features of womens' language that gave negative response as "no", "not existing all features".

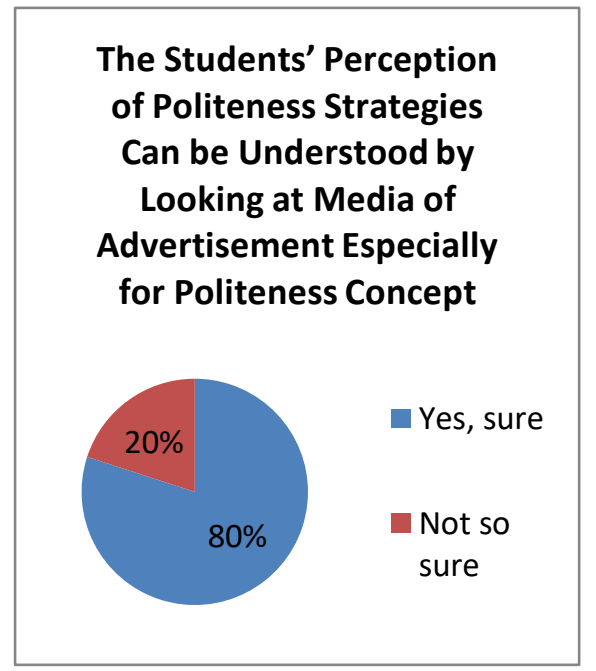

Diagram 5. Percentage of students,
perception about finding
and understanding the
politeness concept
The related graph of the question of "The students' perception of all of featuresof women's language can be understood by looking at media of advertisement especially for gender concept" were responded as:

1. Yes, sure 80 percentage

2. Not so sure 20 percentage

In this part of questions, the students should think about the politeness strategies existed in the media of advertiement. To make understand of the existance of the politeness strategies used, here were the explanation of the politeness strategies of each part. The first strategy is bald on-record strategy. It is a direct way of saying things. The second strategy is positive politeness strategy. This strategy showed that the speaker recognize the hearer has willingness to be approved. This strategy is part of positive face. The third strategy is negative politeness strategy. This strategy used as a way to interact with the hearer in a nonimposing way. The fourth strategy is offrecord indirect strategy. It is used to remove the speaker form any potential of preventing the Face Treatheaning Act (FTA) with implicature, or with implied meaning, or ambigu. From all explanation above, the students would think the politeness strategies before responding of this part of question about student's perception of the existence of the politeness strategies can be understood or not especially for politeness concept by Brown and Levinson's theory.

From the graph above, the percentage showed that the most dominant poin about 80 percentage was in positive response, "Yes, sure". However, only 20 percentage was in negative response, not effective. It could be stated that the students' perception of this question.

6. Which media of advertisement would you prefer to watch? An advertisement mostly women or mostly men? 
The responses of the students of the question "the media of advertisement that students preferred to watch" were responded as:

1. Mostly Women 60 percentage

2. Mostly Men 40 percentage

From this part of question, the result of the responses of the media of advertisement that students preferred to watch, mostly women or mostly women can be seen in the following graph.

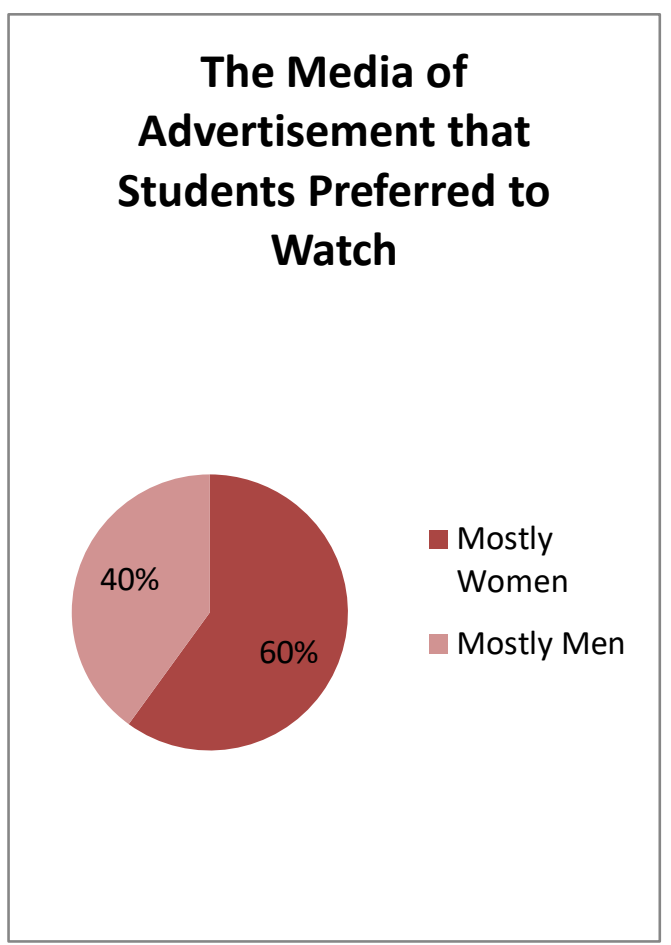

Diagram 6. Percentage of the media of advertisement that students preferred to watch

As it was clear from the diagram above, most of students responded that they would prefer the media of advertisements mostly women to mostly men. There were about 6 students out of 10 students stated that they would prefer mostly women in someway. As a response to this question, students also stated that their reason why the students chose the advertisement mostly women. On the other hand, there were only about 4 students out of 10 students stated that they would prefer mostly men in someway. The response to this questions varied as their preferences to the theme of the media of advertisement given to the mostly men advertisement. The reasons were mostly about this following utterances as follows:

a. Statement 1: "I prefer woman, because I can find many linguistic features of woman language and it is so touchable".

b. Statement 2: "I prefer man, because I like the natural habbits and challenging theme".

\section{CONCLUSION}

Based on findings and discussions in this study, it could be concluded that the students' perception of the use of media of advertisement in understanding of the politeness and gender concept were in positive response. The explanation of the results and discussions were shown by these points as follows.

The students' perception of the use of media of advertisement were divided into six questions of semi-structured interview. The questions can be seen as follows. The first questions was "Do you think media of advertisement is an effective technique to gain the information of politeness and gender concept?". The second question was "What are the positive effect of using media of advertisement in politeness and gender concept? The third question was "What are the negative effect by using media of advertisement in politeness and gender concept? The fourth question was "Do you think that all of the features of women's language can be understood by looking at media of advertisement especially for gender concept by Lakoff theory?" The fifth question was "Do you think that all of the politeness strategies can be understood by looking at media of advertisement especially for politeness concept by Brown and Levinson theory?" The sixth question was "Which media of advertisement would you prefer to watch? An advertisement mostly women or mostly men?" 
1. From the first question of media of advertisement as an effective technique, the students' perceptions mostly gave positive response as the effecetive technique.

2. From the second question of the positive effect of the use of media of advertisement, the students' perception gave in different responses, as can be divided into motivating, not boring, clear conversation, understandable, and fun.

3. From the third question of the negative effect of the use of media of advertisement, the students' perception gave in different responses, as can be divided into only few linguistic features, not in normal setting, selected advertisements, a lot of disturbing motions.

4. From the fourth question of the students' perception of the use of media of advertisement especially in politeness concept. It showed that mostly students gave the positive respon as "yes" response of 70 percentage.

5. From the fifth question of the students' perception of the use of media of advertisement especially in gender concept. It showed that mostly students gave the positive respon as "yes" response of 80 percentage.

6. From the last question of the students preference of videos of advertisement, the students' perception gave in different responses, as the media of advertisement of mostly women of dominant in percentage, however the media of advertisement of mostly men of in small number.

7. In this research, only few of Lakoff's theory of women's language were found in advertisement this was in line with the research by Aini (2016).

8. Furthermore, in general, the media of advertisement often use the similar strategy, like a positive politeness strategy. The result of this research was in line line with the research by
Pangestuti (2015); by Elmianvari and Kheirabadi (2015); by Wambui (2014) which used the positive politeness strategy.

9. In addition to future researcher, the researcher needs to develop more questions based on other type of interview, except semi-structured interview.

\section{BIBLIOGRAPHY}

Aini, L. M. (2016). Women language used by the main characters of "Mockingjay" movie. Thesis for S1 degree. English Language and Letters Department: Maulana Malik Ibrahim State Islamic University of Malang.

Bansal, M. and Gupta, S. (2014). Impact of newspaper advertisement on consumer behavior. Global Journal of Finance and Management, 6 (7), 669-674.

Culpeper, J., Haugh, M., and Kádár, D. Z. (Eds). (2017). The palgrave handbook of linguistic (im)politeness. London: Palgrave Macmillan.

Elmianvari and Kheirabadi. (2015). "The study of EFL students' requests based on politeness theory". Journal of Language Teaching and Research, 4(2), 375-385.

Hameed, W. Q. (2010). The impact of gender in determining politeness strategy with reference to Iraqi students of English. Journal of the College of Arts, 54(2), 38-56.

Harfoushi O., Alfawwaz, B., Obeidat, B., Obeidat, R., and Faris, H. (2013). Impact of internet advertisement and its features on e-commerce retail sales: Evidence from Europe. Journal of Software Engineering and Applications. 6, 564-570.

Holmes, J., and Wilson, N. (2017). Learning about language: An introduction to sociolinguistics. 
Fifth Edition. Essex: Pearson Education Ltd

Hornby, A.S. 2018. Oxford Learners' Dictionary (Online). Retrieved from

https://www.oxfordlearnersdictiona ries.com/definition/english/a-shornby

Karimkhanlooei, G. and Vaezi, N. (2017). Politeness strategies in written communications: The issue of Iranian EFL learners. Jolace: Journal of Language and Cultural Education, 5(3), 108-126. doi: 10.1515/jolace-2017-0031.

Khalik, L. A. and Supatmiwati, D. (2016). Politeness strategies as persuasive tool used in Lombok commercial magazines. Merit Research Journal. 4(11). 158-167

Meyerhoff, M. (2018). Introducing sociolinguistics $\left(3^{\text {rd }}\right.$ ed.). New York: Routledge.

Pangestuti, W. (2015). Politeness strategies used by Deddy Corbuzier in interviewing entertainer and nonentertainer in "Hitam Putih" talk show. Thesis for S1 degree. English
Department: University of Diponegoro.

Saidi and Khosravi. (2015). EFL Learners' perceptions of (im)politeness: The possible gender differences. International Journal of Language and Applied Linguistics, 1(1), 1-11.

Siddiqui, S., and Singh, T. T. (2016). Social media its impact with positive and negative aspects. International Journal of Computer Applications Technology and Research. Vol.5, Issue 2, $71-75$.

Stamatelou, M. (2015). A reflection on the use of Advertisements in enabling language learning in the EFL classroom. Elted, Vol. 17 Winter, 27-34.

Wambui, N. S. (2014). Linguistic politeness strategies in bank advertisements: A case study of Kenya commercial bank. Thesis for master degree. Department of Linguistics and Languages: University of Nairobi.

Wardhaugh, R. and Fuller, J. M. (2015). An introduction to sociolinguistics ( $7^{\text {th }}$ ed.). Oxford: Wiley Blackwell 